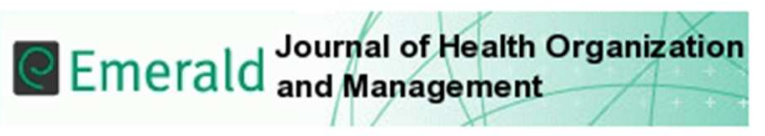

\title{
Between Consensus and Contestation
}

\begin{tabular}{|r|l|}
\hline Journal: & Journal of Health Organization and Management \\
\hline Manuscript ID & JHOM-03-2016-0040.R1 \\
\hline Manuscript Type: & Original Article \\
\hline Keywords: & $\begin{array}{l}\text { Public participation, Priority setting, Deliberative democracy, Agonistic } \\
\text { democracy }\end{array}$ \\
\hline \multicolumn{2}{|l}{} \\
\hline
\end{tabular}




\title{
Between Consensus and Contestation
}

\begin{abstract}
Purpose: Noting that discussions of public participation and priority setting typically presuppose certain political theories of democracy, the paper discusses two such theories: the consensual and the agonistic. The distinction is illuminating when considering the difference between institutionalized public participation and contestatory participation.
\end{abstract}

Design/Methodology/Approach: The approach is a theoretical reconstruction of two ways of thinking about public participation in relation to priority setting in health care, drawing on the work of Habermas, a deliberative theorist, and Mouffe, a theorist of agonism.

Findings: The different theoretical approaches can be associated with different ways of understanding priority setting. In particular, agonistic democratic theory would understand priority setting as system of inclusions and exclusions rather than the determination of a consensus of social values, which is the typical deliberative way of thinking about the issues.

Originality/Value: The paper shows the value of drawing out explicitly the tacit assumptions of practices of political participation in order to reveal their scope and limitations. It suggests that making such theoretical presuppositions explicit has value for health services management in recognizing these implicit choices.

Keywords: Public participation, priority setting, deliberative democracy, agonistic democracy.

Paper Type: Conceptual paper. 


\section{Between Consensus and Contestation in Priority Setting}

A striking feature of discussions about public participation and priority setting in health care is the extent to which they draw upon concepts and categories found in political theory. For example, in her discussion of the relationship between public participation and public deliberation, Blacksher (2014: 4) cites the work of Chambers (2003: 309). Public deliberation is seen as being aimed at securing legitimacy and the criteria of legitimacy are derived from deliberative democratic theory, requiring participation to be inclusive, equal, reasoned and voluntary. In her analysis of the Israeli Health Parliament, Guttman (2007: 411) sees participative public deliberative practices as ways of creating the conditions of the 'public sphere' theorized in the work of Habermas. Guttman uses this Habermasian characterization to evaluate how well the Health Parliament realized public deliberation in practice. Oh et al. (2015) describe the moves towards the First Citizen Committee for Participation in South Korea as being inspired by ideas of 'accountability for reasonableness' as adumbrated in the work of Daniels and Sabin (2008). Abelson et al. (2013: 4) locate the origins of experiments in public deliberation within the theory of deliberative democracy, noting that the legitimacy of the decisions at which public deliberation is aimed rests upon the participants being diverse, with each person having an equal opportunity to participate in discussion on the basis of non-partisan information.

Political theories in public administration are typically used by analysts and policy-makers for two inter-related purposes. The first is to explicate the rationale of practices like public participation. The second is to stipulate the normative requirements for such practices by defining relevant evaluative criteria. So, if deliberative theory is taken as the background theory for public involvement in decision making, then any actual example of public involvement can be evaluated by the extent to which it meets standards such as inclusiveness and adequate descriptive representation in the selection and facilitation of participants.

These normative criteria of performance can also be extended to evaluate actual practices of policy making. For example, from a deliberative perspective, there is a contrast to be made between policy processes in which lobbying dominates deliberation. Deliberative criteria then provide the grounds to criticize existing processes as well as the rationale for a more open and inclusive alternative. On such a view, only some forms of public participation are to be encouraged; others are at best a distraction and at worst a barrier to fair priority setting. From this deliberative perspective, decision making should be detached from the influence of organized patient groups (patient 'lobbies') advancing their particular interests, in order to provide a forum within which broadly shared social values can be brought to bear on priority setting issues. For example, it is sometimes argued, inclusive and representative minipublics, by contrast with patient protest groups, will take a dispassionate point of view judging issues from the standpoint of the citizen. Public participation through formal representation or minipublics issues in negotiated consensus; contestatory participation issues in conflict.

If the principles of deliberative democratic theory are privileged in this way, it follows that what is needed, in order to improve public participation in the management of priority setting, is a more thorough and rigorous application of the principles of deliberative democratic theory. If deliberative theory is then linked to ideas of accountability for reasonableness, institutions and practices will need to be created in which reasonable views are expressed and channels of communication opened that foster negotiated consensus. 
Yet this way of viewing the theoretical dimension of public participation is not the only one possible. As the analysis of cross-national patterns of public participation in this special issues of the Journal of Health Organization and Management shows (Slutsky et al., 2016), patterns of public participation exhibit considerable variation in the form and style that participation can take. At one end there is institutionalized participation through the involvement of patient and public representatives as formal members on decision making bodies, as well as the use of minipublics. Thus, NICE has strong institutionalized forms of public involvement. At the opposite end are health systems like Brazil, Colombia, South Africa and South Korea in which participation takes a contestatory form, employing tactics of court proceedings, demonstrations, protests and direct lobbying. It is, of course, possible to say that, where contestatory participation prevails, what is needed is an injection of deliberative democratic practices and norms. Yet it is only feasible to implement particular normative principles provided certain conditions obtain. A policy-making system that is in general exclusionary or that lacks the administrative capacity to deliver on even a basic level of service is also likely to be one in which the results of participatory decisions are marginalized or ignored.

Concerns about the implementation of particular theoretical approaches and principles feed back into thinking about the rationale of participative practices. Instead of taking the norms, criteria and principles of deliberative theory as having universal application, the concepts and categories of democratic theory can be seen as ways of characterizing the forms of participation specific to different political practices. From this point of view, contestatory forms of participation may not of themselves be undemocratic, failing to meet standards of reasonable deliberation. Rather they are a specific type of democratic response in a political situation in which reasonableness is for losers. Whether public participation should be consensual or contestatory can only be decided once we have determined the appropriate way of theorizing the practices and institutions in which priority setting is embedded.

This paper seeks to meet this challenge, posing the question of what alternative types of democratic theory are appropriate to different political circumstances. It takes two paradigmatic theories deliberative democracy as formulated by Habermas (1996) and agonistic democracy as formulated by Mouffe (2005) - as contrasting ways of theorizing the possible relationships between priority setting and public participation. These two theories are not the only theoretical alternatives. For example, among deliberative theorists there are competing views about the extent to which minipublics need to aim at consensus with some, like Gutmann and Thompson $(1996 ; 2004)$ urging the deliberative theory can be formulated in cases of persistent and deep moral disagreement. Similarly, among some agonistic theorists, like Tully $(2005 ; 2008)$, open deliberation is a way of dealing with difference. However, the sharply contrasting character of deliberative and agonist democracy in the work of Habermas and Mouffe provides a finely etched contrast of perspective that makes it possible to see more clearly how different modes of public participation may be best theorized.

The paper proceeds as follows. Section 1 gives a brief account of Habermas's theory of deliberative democracy. Section 2 introduces Mouffe's theory of agonistic democracy in which identity is always a matter of difference, and according to which the contestatory role of democratic action is seen as central. Section 3 draws out the implications for these two lines of analysis for our thinking about public participation and priority setting, noting that we cannot expect democracy in health policy to compensate for the lack of democracy in the political system at large. 


\section{Deliberative Democratic Theory}

Within the perspective of deliberative democracy, a number of theorists take consensus as central to legitimate decision making. For example, Cohen (1989: 22) writes that political outcomes are legitimate 'if and only if they could be the object of free and reasoned agreement among equals'. Similarly Dryzek (2001: 651) holds that 'outcomes are legitimate to the extent to which they receive assent through participation by all those subject to the decision in question'. Such ideas are found in the design of participative deliberative processes. Thus Guttman (2007: 418-22) shows how in the Israeli Health Parliament measures were taken to ensure fairness in recruitment procedures, access to information and stipulations of competence, as well as procedures to ensure an inclusive discursive process, conditions necessary to secure agreement by participants on an equal footing and in a free and reasoned way. In this tradition of thinking, Habermas has offered an important and influential theory of deliberative democracy in which the idea of consensus is central, not as an incidental element of theory but as crucial to its basic construction. In turn, his theoretical construction has important implications for practices of public participation, as well as having been influential on theorists of minipublics like Dryzek (Dryzek and Niemeyer, 2008).

Habermas's account of deliberative democracy is a theory of what gives legitimacy to public decisions and policies, where legitimacy means that the norms embodied in those decisions and policies provide justifiable grounds of public action. At the core of his view is the discourse principle defined as follows:

'According to the discourse principle, just those norms deserves to be valid that could meet with the approval of those potentially affected, insofar as the latter participate in rational discourses.' (Habermas, 1996: 127).

In other words, for a norm - a guide as to policy decision-making - to be justifiable, it must be one to which all those affected by the policy could agree. Consensus is not simply a desirable feature of policy making; it is the only basis upon which public policy can legitimately be made.

It is part of the deep background to this theory that there are no objectively right or wrong answers to questions of public policy and public choice (Weale, 2007: 83-90). Legislation cannot identify the right policy apart from the process of public dialogue that gives rise to a social consensus. However, a legitimating consensus requires certain conditions to be met in the process of deliberation, involving constraints on how the public dialogue is to be conducted. In this context, Habermas distinguishes between what he calls strategic rationality on the one hand and communicative rationality on the other. Strategic rationality is typical of situations in which people bargain with one another. For example, two people negotiating over the price of a house are looking to find agreement, but each is still interested in securing the best deal possible from an individual point of view. By contrast, communicative rationality is a frame of mind in which the parties to a disagreement are looking to express the grounds of their beliefs as honestly as possible, with the aim of persuading the other person to see their point of view but also with a willingness to change their own minds if the other side comes up with relevant considerations. According to Habermas, when citizens are debating the ends of collective action in ways that secure legitimacy, they should be understood in engaging in an exercise of communicative rationality, seeking for mutual understanding from a common point of view. 
It is not hard to see why such ideas attract policy makers concerned with the setting of health care priorities. Many of the questions that are raised by priority setting do not have clear and obvious answers. Should there be special consideration for children when evaluating health benefits? What is the role of personal responsibility in decisions on resource allocation? How much it is reasonable to pay for a therapy that promises to extend life in the last few months of someone's life? Is it relevant that a therapy will increase the chance of some patients returning to work, when other therapies are primarily of benefit to the retired? Because these questions have no obvious right answers, the most plausible basis of legitimation seems to be that of consensus. If people can agree on the answers, particularly where people who stand to lose from any decision can agree in recognising valid competing claims from their own, then those formulating policies have a claim to legitimacy in their decisions by reference to that consensus. Emerging from a process of communicative interaction, negotiated consensus seems an attractive basis for public action where there is no simple right answer.

Deliberative theory is not simply a way of deriving principles for the design of deliberative practices and institutions. It is also a way of thinking about the general political processes by which decisions are made, the deliberative system (Parkinson and Mansbridge, 2012), in which there is a division of labour between citizens and their political representatives. Unless citizens' deliberation effectively feeds in to representative systems of government, then the promise of deliberative theory will be lost. This does not mean, however, that an effective deliberative system is organized by the political authorities. Habermas (1996: Chapter 8) himself stresses the role of autonomous civil society groups, who are relatively independent of state institutions and authority, in the public opinion forming process. Such groups operate alongside formal institutions, for example political party representatives voting in a parliament, identifying new issues for the political agenda and providing a critique of existing policies. Nevertheless, social and policy consensus is the goal by which public participation should be judged.

\section{Agonistic Democracy}

A consensus emerging from processes of public participation may be premature if it too easily closes down political controversy. For example, Blacksher (2013: 2-3) has drawn attention to a radical strand of thought in which public participation is seen as a form of citizen power, concerned to give voice to those excluded from effective decision making, rather than a form of institutionalized deliberation. Stewart (2016) has stressed the role of 'uninvited' participation alongside 'invited' participation in the making of decisions. Sluksky et al. (2016) have drawn attention to the central role of contestatory participation in societies like Brazil, Colombia and South Africa. In some cases, the interaction of civil society and the state is not one of shared deliberation about a common form of public life. Rather it takes the form of a critique of exclusion. If that form of participation is to be theorized, then it will be necessary to draw upon theories of agonistic democracy of the sort found in the work of Chantal Mouffe.

By contrast with theorists of democratic consensus, Mouffe is a theorist of difference. Her starting point is that any modern democracy is irreducibly plural. It contains different groups with their own moral and political perspectives. Moreover, these groups have their own identities. Such different identities cannot be merged into an overall social identity, because the creation of an identity implies the establishment of difference, so that any 'we' can only exist in opposition to a 'they' (Mouffe, 2005: 15). It follows that 'the possibility of a universal rational consensus has put democratic thinking on the wrong track' (Mouffe, 2005: 3). What is needed is not the design of impartial institutional 
procedures, capable of reconciling conflicting interests and values, but the creation of a public sphere in which different political projects can confront one another, advocating their respective claims. From this point of view, an idea like 'good governance', sometimes associated with the fostering of public involvement, is an anti-political notion, seeking to erase irreducible differences present in society rather than acknowledge them (Mouffe, 2005: 2).

One of Mouffe's principal concerns is that any putative consensus will always in practice be a form of intellectual and political hegemony excluding certain perspectives, whilst pretending at the same time to be general and impartial. Behind this claim is a more general view that social groups can only realise that they stand in a relation of oppression to a social order if they have access to an alternative way of thinking. For example, serfs can only thing of themselves as oppressed if they have access to a vocabulary of equal rights (Laclau and Mouffe, 1985: 154). Since identities are irreducibly plural, a dominant set of identities within a social order will always exclude another set of identities. To suppose otherwise is to ignore the role of power in the way that politics and policy are constituted.

On this account, deliberative democracy makes a mistake in seeking to moralize political decision making. For Mouffe, such a rationalist and moralistic notion is called into question by the fact that politics is always potentially characterized by the logic of the friend/enemy distinction (Mouffe, 2005: 13-14), which creates political antagonism. Such a relation between friend and enemy can be redefined so that it becomes a contest of adversaries rather than enemies. Relations of political antagonism thus become relations of political agonism in which adversarial contest replaces the opposition of enemies. Unlike enemies, adversaries share assumptions about the basis of the political order, accepting the basic principles of democracy on such matters as political equality. However, these same assumptions will also require them to acknowledge that democracy is about allowing conflict and not imposing an authoritarian order (Mouffe, 2005: 30).

This agonism, it is claimed, acknowledges the role of mass political movements and the passions that they exhibit (Mouffe, 2005: 24), forming a contrast with a deliberative democracy that aims at an impartial and dispassionate politics. Agonistic democracy sees the passions of mobilization, politicization and conflictual representations of the world as central to the democratic project. It is social movements that provide pluralism within a political order, particularly social movements like feminism and anti-racism. In Mouffe's view these movements define their identities in we/they terms. However, although such groups are her principal examples, there is no reason why her conception of identity should not be extended to groups defined by their relation to health care: those concerned with children's health as distinct from those concerned with the health of adults; those suffering longterm conditions as against those with acute conditions; those suffering from AIDS; or those with mental illness.

What would it imply for the politics of priority setting to understand it as built upon this agonistic account of democracy? Mouffe has not herself discussed the politics of priority setting, but her concept of agonism suggests the following. From an agonistic point of view, the setting of priorities is not a matter of producing a rank-ordering of cost-effective interventions, defined impartially. Rather it would be a system of inclusions and exclusions. One type of inclusion or exclusion would relate to which interventions - whether they be pharmaceuticals, medical devices or other procedures - were either covered or not covered for reimbursement. However, exclusions might also extend to types of patients, for example the elderly or those thought to have brought illness upon themselves, the latter being an element in such cases as sofosbuvir for Hepatitis C (Kieslich et al., 2016). Inclusions and exclusions also need to be determined in respect of the types of evidence that would 
count in favour or against the coverage of an intervention, as well as to what counted as illness rather than a matter of social care, disability or infertility. On this account, those who manage priority setting are no longer the servants of a negotiated and agreed consensus in the public interest. Rather their function is to police a system of inclusions and exclusions.

Because the source of these inclusions and exclusions is to be found in the dominant or hegemonic paradigm of decision making, for agonistic theorists all the presuppositions of the decision making paradigm are subject to political contestation. Consider, for example, the prices charged for pharmaceuticals as an element in the decision on priorities. On the agonistic account, pharmaceutical prices are not natural givens but stem from rules of intellectual property, the influence of regulatory regimes as well as accounting conventions about such matters as write-offs for losses, investment tax allowances and cross-product subsidy. These social constructions underlie the inclusions and exclusions that shape priority setting. As such they are potentially open to political challenge. Similarly, applying principles of cost-effectiveness to prioritise interventions presupposes that is it possible to generate a social consensus about such matters as relative rankings of the quality of life and the commensurability of health gain across many different conditions. Such assumptions are frequently built into the routine processes of health technology assessment. However, as the experience of HIV/AIDS drugs in many societies has shown, decisions on particular interventions can trigger contestation over such tacit assumptions. In this way, an agonistic account of democracy theorizes how the scope of political conflict is sometimes widened in respect of inclusions and exclusions by particular issues that call into play significant identity formations.

From the agonistic perspective, the use of minipublics in priority setting risks exclusion through agenda-setting, another form of hegemony. Minipublics are the epitome of what Stewart (2016) has labelled 'invited' participation. Those who offer the invitation are also the ones who organized the event, with consequent control of process and procedure (Gul, 2015). The initial agenda is defined for participants; minipublic events usually take place under conditions designed to soften rather than enhance difference; briefing materials and the experts used will inevitably reflect only partial understandings of complex situations; and limitations of time and resources will always result in the exclusion of various, and dissenting, voices. As organized events, their character will reflect the bureaucratic rationality that led to their establishment. An example of these effects is provided by the Israeli Health Parliament, which asked citizens to deliberate on priorities on the assumption of a fixed budget. Some participants rejected this starting-point, as in the following quotation from one participant shows:

'I say that we don't have to speak from the logic that we need to follow what we are asked to do. We need to decide from our own conscience if to give funding to an expensive treatment for a patient or abandon him.' (cited in Gutmann, 2007: 427)

As Guttman points out, such attempts to reject the given framework of discussion were in turn rejected by other participants. From an agonistic point of view, the rejection of the rejection exemplifies the logic of inclusions and exclusions.

Given that identities can only be articulated by those that share them, the agonistic democrat is likely to place more faith in autonomous patient movements, political campaigns and the mobilization of movements than in administratively organized public deliberation. An example would include South Africa's Treatment Action campaign seeking to gain access to HIV/AIDS therapies (Slutsky, et al. 2016). The Campaign's use of the South African constitutional right to health was both a focal point 
for mobilization and a case of agonistic, rather than antagonistic, political action. It presupposed acceptance of the basic constitutional order of society, and so was not premised on the distinction of friend/enemy. It did contest how an agreed basis of democracy was being interpreted, the precise way in which inclusions and exclusions were constructed.

\section{Consensus or Agonism?}

It can be argued that the contrast between deliberative and agonistic theories of democracy is less sharp than has been presented so far. For example, some agonistic theorists like Tully $(2005,2008)$ see deliberation in minipublics as a way of opening up technical and other forms of decision making to political contestation (compare Wingenbach, 2011), although this line of argument is challenged from the agonistic perspective (Wenman, 2013: 162). In more theoretical terms, Mouffe's appeal to some underlying procedural consensus that turns enemies into adversaries and the use of language in contestation can be argued to presuppose some discursive agreement (Knops, 2007). Yet, to say that there is overlap is not to say that there is similarity at a deep level. The contrasting ways in which deliberative and agonistic accounts theorize public participation reflects the way in which agonistic theory offers an irreducibly conflictual view of the political world by contrast with deliberative theory (Gürsözlu, 2009).

What implications do these differences in democratic theory carry for the organization of public participation in relation to priority setting? One implication is the need to pay attention to the way in which institutionalized participation, either in minipublics or through appointed public representatives, relates to the understanding of public opinion. Public opinion can be thought of in various ways, but it distorts the priority setting agenda if it is only seen through its construction in questionnaire responses or through the deliberated responses of minipublics. It may be, for example, that the mobilization of patient groups around access to therapies biases a policy process that in less passionate circumstances would reject the claims made by such groups. On the other hand, such mobilization is one form of public opinion that is no less authentic than the construction of public opinion through devices like opinion surveys or deliberative events.

In this respect there is one important way in which deliberative and agonistic theory overlap. Just as some agonistic theorist embrace minipublics, so a deliberative theorist like Habermas sees an important opinion-forming role for autonomous political movements within civil society. Although Habermas does not conceive of the logic of social movement organization as agonistic, his model allows for a transformation of politics when currents of thought, previously outside the sphere of routine politics, contest the normal order and establish their concerns in the political or parliamentary system. This was the pattern of German environmental politics from the late 1960 s to the 1980 s, in which the so called 'citizens' initiatives' mobilized around questions of town planning, redevelopment and traffic management (Weale, 1992: 168). These civil society movements contributed to a transformation of environmental politics and policy. By analogy, it is not difficult to see a political logic by which disillusion with the high costs of medical care transforms itself into social mobilization to improve public health particularly in respect of such matters as air pollution, food security and access to recreational space.

Mouffe's distinction between agonism and antagonism draws attention to the conditions that need to be in place for broad civic participation is to make legitimate priority setting decisions. Agonism requires that there be some consensus on the rules of the game if not on the substantive decisions. In 
the societies in which contestatory participation is the norm, the conditions of democratic consolidation, including the socio-economic securities that underlie meaningful democratic participation are absent. Where the security of economic and social rights is lacking, even when promised in the constitution, it is not surprising that participation is contestatory rather than consensual. As such, it is better theorized through the concepts of agonistic democracy than through the ideals of deliberative democracy. In particular, it should not be assumed that creating islands of deliberative democracy in a society in which the broader social and economic rights of citizenship are insecure will enhance the legitimacy of priority setting.

In this context, the administrative capacity of the state is crucial. Democratic participation is only effective insofar as there is a relatively efficient and uncorrupt state administration to carry into effect the will of the public. Ineffective state structures will compromise the ability to appraise interventions, raise revenue, shape investments and ensure that services are provided in line with public needs and preferences. Good management and organization are at the heart of any attempts to ensure that public participation plays a role in priority setting. If public participation is to be transformative, then health care organization and management will need to create the conditions in which meaningful participation is possible, whilst always being sensitive to the democratic categories and concepts that infuse the actions of policy makers. 


\section{References}

Abelson, J., E.A. Blacksher, K.K. Li, S. E. Boesveld and S.D. Goold (2013) "Public Deliberation in Health Policy and Bioethics: Mapping an Emerging, Interdisciplinary Field", Journal of Public Deliberation, Vol. 9 No. 1, Article 5. Available at:

http://www.publicdeliberation.net/jpd/vo19/iss1/art5/.

Blacksher, Erika (2013) "Participatory and Deliberative Practices in Health: Meanings, Distinctions, and Implications for Health Equity”, Journal of Public Deliberation, Vol. 9 No. 1, Article 6.

Available at: http://www.publicdeliberation.net/jpd/vol9/iss1/art6.

Chambers, S. (2003) "Deliberative Democratic Theory", Annual Review of Political Science, Vol. 6, pp. 307-26.

Cohen, J. (1989) "Deliberation and Democratic Legitimacy" in A. Hamlin and P. Pettit (eds), The Good Polity: Normative Analysis of the State (Oxford: Basil Blackwell), pp.17-34.

Daniels, N. and Sabin, J.E. (2008). Setting limits fairly: learning to share resources for health. $2^{\text {nd }}$ Edition (Oxford: Oxford University Press).

Dryzek, J. and Niemeyer, S. (2008), "Discursive Representation", American Political Science Review, Vol. 102 No. 4, pp. 481-93.

Dryzek, J.S. (2001), "Legitimacy and Economy in Deliberative Democracy”, Political Theory, Vol. 29 No. 5, pp.651-69.

Gul, V. (2015) Organized Citizen Deliberations: An Examination of Representation, Accountability and Effectiveness in the Context of Minipublics, $\mathrm{PhD}$, University College London.

Gürsözlu, F. (2009) “Agonism and Deliberation - Recognizing the Difference”, Journal of Political Philophy, Vol. 17 No. 3, pp. 356-68.

Gutmann, A. and Thompson, D. (1996) Democracy and Disagreement (Cambridge, Mass.: Harvard University Press).

Gutmann, Amy and Dennis Thompson, (2004) Why Deliberative Democracy? (Princeton and Oxford: Princeton University Press).

Guttmann, N. (2007) "Bringing the Mountain to the Public: Dilemmas and Contradictions in the Procedures of Public Deliberation Initiatives That Aim to Get "Ordinary Citizens" to Deliberate Policy Issues”, Communication Theory, Vol. 17, pp. 411-38.

Habermas, J. (1996) Between Facts and Norms, translated by William Rehg (Cambridge: Polity Press).

Kieslich, K., Ahn, J., Badano, G., Chalkidou, K., Cubillos, L., Hauegen, RC., Henshall, C., Krubiner, C., Littlejohns, P., Lu, L., Pearson, S., Rid, A., Whitty, JA, Wilson, J. (2016), "Public Participation in Decision-Making on the Coverage of New Antivirals for Hepatitis C", Journal of Health Organization and Management, Vol. 30 this issue.

Knops, A. (2007) “Agonism as Deliberation - On Mouffe's Theory of Democracy”, Journal of Political Philosophy, Vol. 15 No. 1, pp. 115-26. 
Laclau, E. and Mouffe, C. (1985) Hegemony and Socialist Strategy: Towards a Radical Democratic Politics (London and New York: Verso).

Mouffe, C. (2005) On the Political (London and New York: Routledge).

Oh, Juhwan, Ko, Young, Alley, Allison Baer and Kwon, Soonman (2015) "Participation of the Lay Public in Decision-Making for Benefit Coverage of National Health Insurance in South Korea", Health Systems and Reform, Vol. 1 No. 1, pp. 62-71.

Parkinson, J. and Mansbridge, J. (eds) (2012) Deliberative Systems: Deliberative Democracy at the Large Scale (Cambridge: Cambridge University Press).

Slutsky, J., Tumilty, E., Max, C., Lu, L., Tantivess, S., Hauegen, RC., Whitty, JA, Weale, A., Pearson, S., Tugendhaft, A., Wang, H., Staniszewska, S., Weerasuriya, K., Ahn, J. and Cubillos, L. (2016), "Cross-National Patterns of Public Participation", Journal of Health Organization and Management, Vol. 30 this issue.

Stewart, E. (2016) Publics and Their Health Systems (Houndmills: Palgrave Macmillan).

Tully, James (2005) 'Exclusion and Assimilation: Two Forms of Domination in Relation to Freedom', in Melissa S. Williams and Stephen Macedo (eds), Political Exclusion and Domination (New York and London: New York University Press), pp. 191-229.

Tully, James (2008) Public Philosophy in A New Key. Volume I: Democracy and Civic Freedom (Cambridge: Cambridge University Press).

Weale, A. (1992) The New Politics of Pollution (Manchester and New York: Manchester University Press).

Weale, A. (2007) Democracy (Houndmills: Palgrave Macmillan, second edition).

Wenman, Mark (2013) Agonistic Democracy: Constituent Power in the Era of Globalisation (Cambridge: Cambridge University Press).

Wingenbach, Ed (2011) Institutionalizing Agonistic Democracy: Post-Foundationalism and Political Liberalism (Farnham: Ashgate).5288 